\title{
Residual Soil Fertility and Yield in Pigeon Pea, Pearl Millet and Green Gram As Influenced by Intercropping Systems Under Western Haryana Condition
}

\author{
Niranjan Kumar Barod, Satish Kumar and Mohammad Irfan* \\ Department of Agronomy, CCS HAU Hisar-125004, India \\ *Corresponding author
}

\author{
A B S T R A C T
}

\begin{tabular}{|c|}
\hline Keywords \\
\hline $\begin{array}{l}\text { Pigeon pea, Pearl } \\
\text { millet, Green gram, } \\
\text { Intercropping } \\
\text { systems. }\end{array}$ \\
\hline Article Info \\
\hline $\begin{array}{l}\text { Accepted: } \\
\text { 24 February } 2017 \\
\text { Available Online: } \\
10 \text { March } 2017\end{array}$ \\
\hline
\end{tabular}

The investigation entitled "Response of nitrogen application in wheat succeeding pigeon pea intercropped with pearl millet and green gram" was carried out at Agronomy research farm of Chaudhary Charan Singh Haryana Agricultural University, Hisar during kharif and rabi season 2011-12 and 2012-13. It comprised of 12 treatments were replicated thrice in randomized block design. Based on aforesaid investigation it was found that intercropping systems influenced the grain, straw and biological yield significantly were highest in sole crop i.e. pigeon pea (1983 and 2059, 2059 and 5947 and 7777 and $8006 \mathrm{~kg} \mathrm{ha}^{-1}$ ), pearl millet (2122 and 2218, 5999 and 6200 and 8121 and $8418 \mathrm{~kg} \mathrm{ha}^{-1}$ ) and green gram (1319 and 1402, 3925 and 4175 and 5244 and $5576 \mathrm{~kg} \mathrm{ha}^{-1}$ ) respectively during 2011 and 2012 crop seasons. Highest $\mathrm{N}$ availability was recorded under green gram sole which did not differ significantly from various intercropping treatments except pearl millet sole. Significantly lowest $\mathrm{N}$ availability was recorded under pearl millet sole during 2011 and 2012 crop seasons.

\section{Introduction}

Pigeon pea (Cajanus cajan L.) also known as arhar, tur or red gram is one of the most important kharif pulse crop cultivated in India. It is next to only chickpea in area and production among all pulse crop grown in India. Pigeon pea grown as a sole crop is not economically viable because of its slow initial growth rate, low productivity and longer duration. Because of slow growth the crops face a lot of competition with weeds and the inter-row space was not utilized properly (Velaytham et al., 2003). In order to have better utilization of the resources, growing a short duration intercrop like green gram and pearl millet between the pigeon pea rows helps in utilization of available resources without affecting its productivity, short duration and short statured crops like pearl millets and green gram and would prove to be a viable intercropping system. Intercropping with short duration pulses like green gram and cereals like pear millet in pigeon pea enhance total productivity (Sharma et al., 1995). Green gram (Vigna radiata L.) is also an important kharif pulse crop of India. It is an excellent source of high quality protein. As short duration crop it fit well in various multiple and intercropping systems (Pujari and Sheelvantar, 2002). Pearl millet (Pennisetum glaucum L.) is one of the most important rain fed crop of India. Its grains possess higher protein content with higher level of essential amino acids. The inclusion of pearl millet with pigeon pea will definitely ensure the 
fulfillment of dietary requirement and enhanced productivity of crops per unit area per unit time (Anonymous, 2004).

Intercropping is an age-old practice being followed by subsistence farmers to achieve their domestic needs. The main advantage of the intercropping is that the component crops are able to use the growth resources more efficiently (Willey, 1979). Nitrogen needs of cereals intercropped with legumes are reported to be less than for sole cropping due to transfer of some of the fixed nitrogen by legumes to the associated cereals during the growing season (Willey, 1979). Intercropping of legumes with pearl millet has been reported to be more stable and dependable than sole cropping (Patel et al., 1998). In intercropping systems, selection of compatible crops with different growth pattern and their suitable planting geometries are very important because, it helps to minimize inter and intra specific competitions for resources. A lot of work has been done on nutrient management in pigeon pea and wheat crop alone. However, very less information is available on the effect of pearl millet, green gram intercropping in pigeon pea. Therefore, in view of the above, the present investigation was planted.

\section{Materials and Methods}

The experiment was conducted at the Agronomy Research Farm, CCS Haryana Agricultural University, Hisar during 2011 and 2012. It is situated at $29^{\circ} 10 \mathrm{~N}$ latitude, $75^{\circ} 46^{\prime}$ E longitude and at an altitude of 215.2 meters above mean sea level, the experiment was laid out in randomized block design in Kharif. The kharif crops pigeon was as sole and in combination with pearl millet and green gram at different spacing and rows in the kharif season during 2011 and 2012 resulting in 12 treatments. In the pigeon pea (Manak), pearl millet (HHB-67 Improved) and green gram (Basanti) was sown on $17^{\text {th }}$
June during the year 2011 and $18^{\text {th }}$ June during the year 2012. The soil of the experimental unit was sandy loam and the soil $\mathrm{pH}$ was 7.8 and 7.9 , while the EC was 0.39 and $0.40 \mathrm{dSm}^{-1}$ during 2011 and 2012, respectively. The organic carbon of the soil was 0.41 and 0.40 per cent during both the years of study. The soils of the experiential field was sandy loam in texture, poor organic matter (0.41) and low in available nitrogen (162 $\left.\mathrm{kg} \mathrm{ha}^{-1}\right)$, medium in available phosphorus $\left(25 \mathrm{~kg} \mathrm{ha}^{-1}\right)$ and high in available potassium (305 kg ha-1) and slightly alkaline in reaction.

\section{Results and Discussion}

\section{Yields of pigeon pea}

The different intercropping systems produce significant variation in yield during both the years of study. Among the different intercropping systems, grain, straw and biological yield of pigeon pea varied significantly with the sole pigeon pea (Table 1). Pigeon pea planted as paired row (30:60 $\mathrm{cm})$ produced statistically similar grain yield as compared to pigeon pea sole planted at 45 $\mathrm{cm}$ row spacing. Paired row sowing of pigeon pea produced 8.24 and 7.74 per cent higher grain yield as compared to pigeon pea at 45 $\mathrm{cm}$ row spacing during 2011 and 2012, respectively. Under different intercropping systems the higher grain yield of pigeon pea was recorded from pigeon pea $(75 \mathrm{~cm})+$ green gram (1:2) systems however; it was at par with the intercropping systems pigeon pea $(75 \mathrm{~cm})+$ green gram $(1: 1)$. It might be due to synergistic effect of component crop. Similar result was obtained by Kumar et al., 2005, and Kumar et al., 2012. The different intercropping systems failed to produce significant variation in harvest index of pigeon pea as compared to sole crop of pigeon pea. 
Table.1 Effect of intercropping systems on yield of pigeon pea

\begin{tabular}{|c|c|c|c|c|c|c|}
\hline \multirow{3}{*}{ Treatment } & \multicolumn{6}{|c|}{ Yield $\left(\mathrm{kg} \mathrm{ha}^{-1}\right)$} \\
\hline & \multicolumn{2}{|c|}{ Grain yield } & \multicolumn{2}{|c|}{ Straw yield } & \multicolumn{2}{|c|}{ Biological yield } \\
\hline & 2011 & 2012 & 2011 & 2012 & 2011 & 2012 \\
\hline Pigeon pea sole $(45 \mathrm{~cm})$ & 1832 & 1911 & 5373 & 5488 & 7105 & 7399 \\
\hline Pigeon pea - Paired row $(30: 60 \mathrm{~cm})$ & 1983 & 2059 & 2059 & 5947 & 7777 & 8006 \\
\hline $\begin{array}{l}\text { Pigeon pea }(75 \mathrm{~cm})+\text { Pearlmillet } \\
(1: 1)\end{array}$ & 1415 & 1593 & 4496 & 4711 & 5911 & 6304 \\
\hline $\begin{array}{l}\text { Pigeon pea }(75 \mathrm{~cm})+\text { Pearlmillet } \\
(1: 2)\end{array}$ & 1384 & 1563 & 4449 & 4550 & 5833 & 6113 \\
\hline $\begin{array}{l}\text { Pigeon pea }(75 \mathrm{~cm})+\text { Green gram } \\
(1: 1)\end{array}$ & 1530 & 1600 & 4416 & 4571 & 5946 & 6171 \\
\hline $\begin{array}{l}\text { Pigeon pea }(75 \mathrm{~cm})+\text { Green gram } \\
(1: 2)\end{array}$ & 1611 & 1684 & 4625 & 4826 & 6236 & 6510 \\
\hline $\begin{array}{l}\text { Pigeon pea }(90 \mathrm{~cm})+\text { Pearlmillet } \\
(1: 1)\end{array}$ & 1329 & 1473 & 4131 & 4280 & 5460 & 5753 \\
\hline $\begin{array}{l}\text { Pigeon pea }(90 \mathrm{~cm})+\text { Pearlmillet } \\
(1: 2)\end{array}$ & 1296 & 1406 & 3959 & 4095 & 5255 & 5501 \\
\hline $\begin{array}{l}\text { Pigeon pea }(90 \mathrm{~cm})+\text { Green gram } \\
(1: 1)\end{array}$ & 1332 & 1503 & 4236 & 4335 & 5568 & 5838 \\
\hline $\begin{array}{l}\text { Pigeon pea }(90 \mathrm{~cm})+\text { Green gram } \\
(1: 2)\end{array}$ & 1369 & 1540 & 4523 & 4458 & 5892 & 5998 \\
\hline $\mathrm{SEm} \pm$ & 73 & 66 & 92 & 102 & 107 & 126 \\
\hline L.S.D. $(p=0.5)$ & 222 & 197 & 268 & 293 & 312 & 364 \\
\hline
\end{tabular}


Table.2 Effect of intercropping systems on yield of pearl millet and green gram

\begin{tabular}{|c|c|c|c|c|c|c|c|c|c|c|c|c|}
\hline \multirow{3}{*}{ Treatment } & \multicolumn{6}{|c|}{ Pearlmillet $\left(\mathrm{kg} \mathrm{ha}^{-1}\right)$} & \multicolumn{6}{|c|}{ Green gram $\left(\mathrm{kg} \mathrm{ha}^{-1}\right)$} \\
\hline & \multicolumn{2}{|c|}{ Grain yield } & \multicolumn{2}{|c|}{ Stover yield } & \multicolumn{2}{|c|}{$\begin{array}{c}\text { Biological } \\
\text { yield }\end{array}$} & \multicolumn{2}{|c|}{ Grain yield } & \multicolumn{2}{|c|}{ Stover yield } & \multicolumn{2}{|c|}{$\begin{array}{c}\text { Biological } \\
\text { yield }\end{array}$} \\
\hline & 2011 & 2012 & 2011 & 2012 & 2011 & 2012 & 2011 & 2012 & 2011 & 2012 & 2011 & 2012 \\
\hline Pearl millet sole $(45 \mathrm{~cm})$ & 2122 & 2218 & 5999 & 6200 & 8121 & 8418 & & & & & & \\
\hline Green gram sole $(30 \mathrm{~cm})$ & & & & & & & 1319 & 1402 & 3925 & 4175 & 5244 & 5576 \\
\hline $\begin{array}{l}\text { Pigeon pea }(75 \mathrm{~cm})+\text { Pearlmillet } \\
(1: 1)\end{array}$ & 1526 & 1618 & 4319 & 4560 & 5846 & 6178 & & & & & & \\
\hline $\begin{array}{l}\text { Pigeon pea }(75 \mathrm{~cm})+\text { Pearlmillet } \\
(1: 2)\end{array}$ & 1680 & 1776 & 4709 & 4903 & 6389 & 6679 & & & & & & \\
\hline $\begin{array}{l}\text { Pigeon pea }(75 \mathrm{~cm})+\text { Green gram } \\
(1: 1)\end{array}$ & & & & & & & 692 & 789 & 2192 & 2502 & 2884 & 3291 \\
\hline $\begin{array}{l}\text { Pigeon pea }(75 \mathrm{~cm})+\text { Green gram } \\
(1: 2)\end{array}$ & & & & & & & 853 & 946 & 2668 & 2957 & 3520 & 3903 \\
\hline $\begin{array}{l}\text { Pigeon pea }(90 \mathrm{~cm})+\text { Pearlmillet } \\
(1: 1)\end{array}$ & 1413 & 1506 & 3933 & 4178 & 5346 & 5684 & & & & & & \\
\hline $\begin{array}{l}\text { Pigeon pea }(90 \mathrm{~cm})+\text { Pearlmillet } \\
(1: 2)\end{array}$ & 1575 & 1667 & 4407 & 4662 & 5983 & 6329 & & & & & & \\
\hline $\begin{array}{l}\text { Pigeon pea }(90 \mathrm{~cm})+\text { Green gram } \\
(1: 1)\end{array}$ & & & & & & & 622 & 714 & 1973 & 2264 & 2594 & 2977 \\
\hline $\begin{array}{l}\text { Pigeon pea }(90 \mathrm{~cm})+\text { Green gram } \\
(1: 2)\end{array}$ & & & & & & & 774 & 867 & 2281 & 2560 & 3055 & 3427 \\
\hline $\mathrm{SEm} \pm$ & 83 & 71 & 295 & 301 & 408 & 414 & 51 & 47 & 68 & 64 & 56 & 121 \\
\hline L.S.D. $(p=0.5)$ & 277 & 237 & 979 & 999 & 1352 & 1373 & 147 & 139 & 201 & 189 & 166 & 357 \\
\hline
\end{tabular}


Table.3 Effect of intercropping systems on soil fertility status after harvesting of kharif crops

\begin{tabular}{|c|c|c|c|c|c|c|}
\hline \multirow{2}{*}{ Treatment } & \multicolumn{2}{|c|}{ Available N $\left(\mathrm{kg} \mathrm{ha}^{-1}\right)$} & \multicolumn{2}{|c|}{ Available $\mathrm{P}_{2} \mathrm{O}_{5}\left(\mathrm{~kg} \mathrm{ha}^{-1}\right)$} & \multicolumn{2}{|c|}{ Available $\mathrm{K}_{2} \mathrm{O}\left(\mathrm{kg} \mathrm{ha}^{-1}\right)$} \\
\hline & 2011 & 2012 & 2011 & 2012 & 2011 & 2012 \\
\hline Pigeon pea sole $(45 \mathrm{~cm})$ & 186 & 187 & 18.04 & 19.45 & 301.95 & 302.59 \\
\hline Pearl millet $(45 \mathrm{~cm})$ & 172 & 171 & 14.28 & 15.10 & 296.60 & 298.40 \\
\hline Green gram sole $(30 \mathrm{~cm})$ & 190 & 192 & 19.10 & 20.25 & 304.54 & 305.44 \\
\hline Pigeon pea - paired row $(30: 60 \mathrm{~cm})$ & 186 & 188 & 17.29 & 18.19 & 301.71 & 301.67 \\
\hline Pigeon pea $(75 \mathrm{~cm})+$ Pearl millet $(1: 1)$ & 175 & 176 & 16.17 & 16.78 & 299.88 & 299.92 \\
\hline Pigeon pea $(75 \mathrm{~cm})+$ Pearl millet $(1: 2)$ & 173 & 175 & 16.06 & 16.72 & 299.22 & 299.85 \\
\hline Pigeon pea $(75 \mathrm{~cm})+$ Green gram $(1: 1)$ & 187 & 188 & 18.07 & 18.71 & 302.31 & 302.73 \\
\hline Pigeon pea $(75 \mathrm{~cm})+$ Green gram $(1: 2)$ & 188 & 189 & 18.44 & 19.13 & 303.40 & 303.35 \\
\hline Pigeon pea $(90 \mathrm{~cm})+$ Pearl millet $(1: 1)$ & 177 & 179 & 15.31 & 16.03 & 298.40 & 299.62 \\
\hline Pigeon pea $(90 \mathrm{~cm})+$ Pearl millet $(1: 2)$ & 176 & 178 & 15.27 & 15.97 & 297.70 & 298.41 \\
\hline Pigeon pea $(90 \mathrm{~cm})+$ Green gram $(1: 1)$ & 183 & 184 & 16.30 & 16.87 & 300.59 & 301.12 \\
\hline Pigeon pea $(90 \mathrm{~cm})+$ Green gram $(1: 2)$ & 185 & 187 & 16.84 & 17.13 & 301.71 & 301.49 \\
\hline $\mathrm{SEm} \pm$ & 2.61 & 2.94 & 1.38 & 1.19 & 2.72 & 2.83 \\
\hline L.S.D. $(p=0.5)$ & 7.71 & 8.69 & $\mathbf{N S}$ & NS & $\mathbf{N S}$ & $\mathbf{N S}$ \\
\hline
\end{tabular}




\section{Yields of pearl millet}

Pearl millet sole crop produced significantly higher grains, straw and biological yield as compared to different intercropping systems. It was 26.31 and 34.73 per cent higher as compared to pigeon pea $(75 \mathrm{~cm})+$ pearl millet $(1: 2)$ and pigeon pea $(90 \mathrm{~cm})+$ pearl millet $(1: 2)$

Irrespective of pigeon pea row spacing two rows of intercrop produced higher grain straw and biological yield as compared to single row though the difference were nonsignificant among them during both year (Table 2). The grain and straw yield was recorded to be significantly higher in sole system over intercropping systems which might be due to higher plant population of pearl millet in sole crop as compared to intercropping systems. Lower yield of pearl millet was recorded from other intercropping treatments because of less number of plants per hectare. Choudhary and Gautam, 2006 and Kuri et al., 2012 also reported similar results.

\section{Yields of green gram}

In case of green gram the grain, straw and biological yield was recorded maximum in sole crop, which was due to more number of plants and better yield attributes of the crop in one side and better interception of sunlight and more photosynthesis resulting into more production of photosynthates and translocation to the economic part on the other side Kumar et al., 2005, and Sharma et al., 2010 also reported similar result (Table $2)$. The higher yield of green gram in pigeon pea $(75 \mathrm{~cm})+$ green gram $(1: 2)$ systems was because of more number of rows of green gram and reduced competition between and within crop plants due to more availability of space (Bishnoi et al., 1987).

\section{Effect on available Nutrients (N, P and $K$ )} in soil after harvest of $k$ harif crop

After the harvest of the experimental crop in each year, available nitrogen in soil increased under various treatments involving sole, intercropping of grain legumes and pearl millet except pearl millet sole. Thus, improvement in available $\mathrm{N}$ was noted under various crop system involving grain legumes either in sole or intercropping systems. This might be ascribed to the fact that grain legume improve the available nitrogen content of the soil through the process of symbiotic nitrogen fixation (Heldt, 1987). Such effects were, however, not apparent in respect to $\mathrm{P}$ and $\mathrm{K}$ after the harvest of experimental crop in individual year (Table 3). Similar result was found by Kujur et al., 2010 .

Based on the two year (2011-12 and 2012-13) field experimentation the study can be concluded as: Among different intercropping systems tested during kharif season, pigeon pea $75 \mathrm{~cm}$ intercropped with two row of green gram was found most suitable.

\section{References}

Anonymous 2004. Sustaining nutritional security. In: Survey of Indian Agriculture, pp. 37-38.

Bishnoi, K.C., Singh, B. and Singh, A. 1987. Studies on compatibility of green gram and blackgram cultivars in pigeon pea based intercropping systems. Indian J. Agron. 32: 127-129.

Choudhary, R.S. and Gautam, R.C. 2006. Influence of cropping systems and nutrient management on nutrient uptake, protein content, yield, productivity and net returns of pearl millet (Pennisetum glaucum). Annals of Agric. Res. New Series, 27(4): 302-305.

Heldt, H.W. 1987. Plant biochemistry and 
molecular biology. Oxford University Press. pp: 277.

Kujur, S. Ahmad, S. Srivastava, G.P. and Singh, C.S. 2010. Performance of pigeon pea (Cajanus cajan L.) intercropping as influenced by row ratio and duration of finger millet (Elusine coracana) cultivars. Indian J. Agron. 55(3): 209-214.

Kumar, P., Rana, K.S. and Rana, D.S. 2012. Effect of planting systems and phosphorus with bio-fertilizers on the performance of sole and intercropped pigeon pea (Cajanus cajan L.) under rainfed conditions. Indian J. Agron. 57(2): 127-132.

Kumar, S., Singh, R.C. and Kadian, V.S. 2005. Compatibility of pigeon pea and green gram intercropping systems in relation to row ratio and row spacing. Legume Res., 28(3): 213-215.

Kuri, B.R., Yadav, R.S. and Kumawat, A. 2012. Evaluation of pearl millet (Pennisetum glaucum) and mothbean (Vigna acconitifolia) intercropping systems in hyper-arid partially irrigated north-western plain zones. Indian $J$. Agric. Sci., 82(11): 993-996.

Patel, M.R., Kalyanasundaram, N.K., Patel, I.S., Patel, J.M., Patel, S.I., Patel, B.M. and Patil, R.G. 1998. Effect of additive and replacement series in intercropping system with pearl millet. Annals of Arid Zone, 37: 69-74.

Pujari, B.T. and Sheelvantar, M.N. 2002. Dry matter accumulation in plant parts of green gram (Vigna radiata) as influenced by cropping system, row proportion and green gram population levels. Indian J. Agric. Res., 36: 156161.

Sharma, A., Rathod, P.S. and. Basavaraj, K. 2010. Agronomic management of pigeon pea (Cajanus cajan L.) based intercropping systems for improving productivity under rainfed conditions. Kamataka J. Agric. Sci., 23(4): 570574.

Sharma, N.N., Sharma, D. and Paul, S.R. 1995. Intercropping of green gram (Vigna radiata), blackgram (Vigna mungo) and sesamum (Sesamum indicum) and pigeon pea (Cajanus cajan L.) under different seeding methods. Indian J. Agron., 40: 386-387.

Velayutham, A., Kalpana, R. and Sankaran, N. 2003. Effect of fertilizer levels on pigeon pea and green gram intercropping systems. Madras Agric. J., 90(10): 607-610.

Willey, R.W. 1979. Intercropping, importance and research need competition and yield advantages. Field Crops, 32(1): 1-10.

\section{How to cite this article:}

Niranjan Kumar Barod, Satish Kumar and Mohammad Irfan. 2017. Residual Soil Fertility and Yield in Pigeon Pea, Pearl Millet and Green Gram As Influenced by Intercropping Systems Under Western Haryana Condition. Int.J.Curr.Microbiol.App.Sci. 6(3): 2233-2239. doi: http://doi.org/10.20546/ijcmas.2017.603.255 